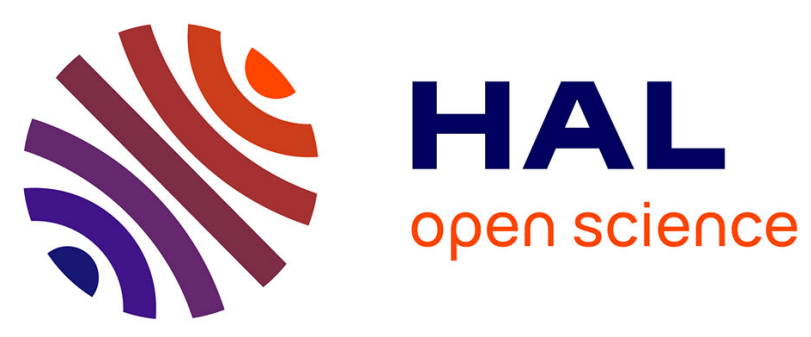

\title{
Toward a sensorial urbanism
}

Mirko Zardini

\section{To cite this version:}

Mirko Zardini. Toward a sensorial urbanism. Ambiances in action / Ambiances en acte(s) - International Congress on Ambiances, Montreal 2012, Sep 2012, Montreal, Canada. pp.19-26. halshs00745041

\section{HAL Id: halshs-00745041 https://shs.hal.science/halshs-00745041}

Submitted on 24 Oct 2012

HAL is a multi-disciplinary open access archive for the deposit and dissemination of scientific research documents, whether they are published or not. The documents may come from teaching and research institutions in France or abroad, or from public or private research centers.
L'archive ouverte pluridisciplinaire HAL, est destinée au dépôt et à la diffusion de documents scientifiques de niveau recherche, publiés ou non, émanant des établissements d'enseignement et de recherche français ou étrangers, des laboratoires publics ou privés. 


\title{
Toward a sensorial urbanism
}

\author{
Mirko ZARDINI
}

Executive Director and Chief Curator at Canadian Centre for Architecture

In recent years, the CCA has set to question at the assumptions on which architects operate. We have embarked on the study and revision of an undeclared territory of false assumptions, preconceptions, and attitudes in an attempt to evidence hidden agendas. We seek to investigate and explore the "grey zone" of contemporary culture, contemporary society, and contemporary architecture to critically expose its contradictions.

Sense of the City (2005) - the first of a series of thematic exhibitions by the CCA - set to challenge the prevalence of the visual in our definition and perception of the environment at the expense of other forms of experience. This attitude allowed us to introduce a viewpoint that favored the active role of users and experience rather than quantity-based ideas like program, function, or efficiency.

The acknowledgment of an alternative framework also offered unexpected possibilities for intervention, suggested new roles and responsibilities, and required new reflections. It presented an unconventional approach towards the concept of experience as a potential tool to properly calibrate the relationship between inhabitants and the built environment. Furthermore, Sense of the City was an effort to define experience not as a private commodity but as a public provision characterized by a multitude of qualities.

The CCA's participation in Ambiances 2012 is inscribed inside a larger effort to study experience in a more critical and productive way. This effort is not directed towards finding or offering possible solutions but in revealing diverse directions and potentials. It is deliberately both a critique of our present conditions and a suggestion for alternative paths.

The following excerpts are part of Toward a Sensorial Urbanism, a text by Mirko Zardini in Sense of the City: An Alternate Approach to Urbanism, originally published in 2005 by Lars Müller Publishers. 
In recent years, numerous studies have taken up the theme of the city and the urban domain. It seems that the city can no longer be avoided: As the predominant setting of our daily lives, it is "everywhere and in everything." ${ }^{11}$ The notion of urbanism as a way of life, independent of the physical density of the environment and thus not dependent on locale, is becoming a concrete reality. ${ }^{2}$

During the 1960s and 1970s, studies and descriptions of the city focused mainly on changes of scale, on the surprising growth that led to the emergence of novel urban configurations. New terms such as metropolitan region, city - region, megalopolis, or megistopolis ${ }^{3}$ gradually began to replace traditional references like city, town, ville, cité, città, Stadt, urbs, and polis, and even metropolis or Großstadt, which were no longer considered adequate to describe the new conurbations. Studies and descriptions of the last decades have attempted to represent the new qualities and increased complexity of urban phenomena. To suggest these new conditions, authors have resorted to adjectives or nouns modifying the word "city." ${ }^{4}$ It is clear from the diverse viewpoints these represent that a unified vision of the urban has been renounced in the face of the complexity of the phenomena being observed and analyzed.

So numerous are the studies and the terms coined in service of this new effort of description and interpretation that they would fill not one but several dictionaries on the subject of the contemporary city: anxious city; city of bits; compact or cyber city... x or Xerox city; year city; Zwischenstadt or zweckentfremdet ${ }^{5}$. Despite their diversity of approach, all of these studies reveal how the cities in which we live have changed, how our ways of looking at the city have changed, and above all, how we ourselves have changed.

\section{Beyond the visual}

Urbanistic studies and urban projects have also attempted to define new strategies of intervention that are capable of effecting transformations of the urban fabric, and of responding to new problems posed by the forces of globalization, de-localization, and fragmentation. From new urbanism to post-urbanism or re-urbanism, from everyday urbanism to informal urbanism, and from eco-urbanism to landscape urbanism, a range of new definitions have been assigned to contemporary city planning in recent years. ${ }^{6}$ The multiplicity of these

1. See the introduction to Ash Amin \& Nigel Thrift, Cities: Reimagining the Urban, Cambridge: Polity Press, 2002.

2. See Louis Wirth, Urbanism as a Way of Life, in The American Journal of Sociology, 1938; Melvin M. Webber, The Urban Place and the Nonplace Urban Realm, in Melvin M. Webber et al., Explorations into Urban Structure, Philadelphia: University of Pennsylvania Press, 1964.

3. Jean Gottmann, Megalopolis: The Urbanized Northeastern Seaboard of the United States, New York: Twentieth Century Fund, 1961. The term "megistopolis" was coined by Gottmann in a 1978 essay entitled How Large Can Cities Grow? reprinted in Since Megalopolis: The Urban Writings of Jean Gottmann, eds. Jean Gottmann \& Robert A. Harper, Baltimore \& London: Johns Hopkins University Press, 1990.

4. In this connection, see Nan Ellin, Slash City, in Lotus international 110, September 2001: 58-72.

5. For a hypothetical dictionary on the contemporary city, see Ludovica Molo \& Mirko Zardini, eds., La città contemporanea dalla A alla Z, in archi, February 1999: 10-45. The compilation of dictionaries is an increasingly common practice today. For a different interpretation, see The Metapolis Dictionary of Advanced Architecture, Barcelona: Actar, 2003.

6. A series of seminars held at the University of Michigan in 2004 offered a first and very interesting panorama; see Rahul Mehrotra, ed., Everyday Urbanism: Margaret Crawford vs. Michael Speaks, Ann Arbor: University of Michigan Press \& A. Alfred Taubman College of Architecture, 2005; Robert Fishman, ed., New Urbanism: Peter Calthorpe vs. Lars Lerup, Ann Arbor: University of Michigan Press, 2005; Roy Strickland, ed., Post Urbanism and Reurbanism: Peter Eisenman vs. Barbara Littenberg \& Steven Peterson - Designs for Ground Zero, Ann Arbor, Michigan: University of Michigan Press, 2005. For the debate on landscape, see James Corner, ed., Recovering Landscape: Essays in Contemporary Landscape Archi- 
designations clearly reflects the wide range of responses and approaches adopted in the face of new urban phenomena worldwide.

There is now widespread interest in the environmental and ecological issues confronting cities, in particular sustainability and biodiversity, and a renewed and general faith in the efficacy of the tools and methods of landscape design to bring about the understanding and transformation of the urban environment. It is not just a question of a reappropriation of the technical instruments, something that is not new, if we look at the experiences of the $19^{\text {th }}$ and early $20^{\text {th }}$ centuries, but rather a conceptual change: we have moved from Boccioni's "city that rises" to the "landscape that advances," metaphorically as well as actually. ${ }^{7}$ As a result, Iñaki Ábalos and Juan Herreros can claim that "every location has begun to be regarded as a landscape, either natural or artificial." ${ }^{8}$

If we look back to the late 1960s and 1970s, we find that the theme of the urban environment was already at the centre of many prescient reflections, most considered radical at the time. However disparate were the viewpoints of that era, from the technological optimism of Buckminster Fuller to the social criticism of collectives like Superstudio, the urban environment seems to have been examined in a broader and more complex manner than in recent decades. ${ }^{9}$ Investigations into phenomenology, for example, though they may not have had widespread impact in the field at large, have surely been a crucial point of departure for theorists like Juhani Pallasmaa and others. This strongly suggests the need for a rethinking of proposals dating from these years, especially because they were framed by political and social issues, debates, and events whose gravity is mirrored by events that are overwhelming cities today. What is clear is that some of the most innovative proposals of the 1970 s exceeded our capacity to realize them at the time, whereas today, they seem not only relevant, but also feasible as events on a global scale transform both the landscape of cities and the hierarchy of our priorities on a daily basis.

It is not a matter of returning to a conception of the environment as purely climatic fact or visual phenomenon, but rather of proposing a broader view of the environment that takes into consideration the full spectrum of perceptual phenomena that make up the sensorial dimension beyond the regime of the visual. Material and tactile properties, the control of temperature, humidity, and odours, along with acoustic qualities are increasingly considered fundamental to the definition of private spaces. Unfortunately, this is not yet the case with urban spaces.

\section{"Sensorial" streets}

The shrinking and impoverishment of so-called public space is now a prominent theme in contemporary debates. Some of the activities once carried out in public space have been taken over by new forms of communal space (i.e., space that is privately owned but in public use, such as shopping malls or theme parks), ${ }^{10}$ while other functions of communication and

tecture, New York: Princeton Architectural Press, 1999, and Mohsen Mostafavi \& Ciro Najle, eds., Landscape Urbanism: A Manual for the Machinic Landscape, London: AA Publications, 2003

7. Mirko Zardini, De la ciudad que sube al paisaje que avanza, in Metròpolis, Ciudades, Redes, Paisajes, eds. Gustavo Gili, Ignasi de Solà-Morales, and Xavier Costa, Barcelona: Gustavo Gili, 2008, 208-212

8. Iñaki Ábalos \& Juan Herreros, Journey through the Picturesque, a Notebook, in Mostafavi \& Najle, Landscape Urbanism 56

9. See Joachim Krausse \& Claude Lichtenstein, eds., Your Private Sky - R. Buckminster Fuller. Design als Kunst einer Wissenschaft, Baden: Lars Müller, 1999, and Your Private Sky: Discourse, R. Buckminster Fuller, Baden: Lars Müller and Museum of Design, Zürich, 2001; on Superstudio, see Emilio Ambasz, ed., Italy, The New Domestic Landscape: Achievements and Problems of Italian Design, exh. cat, New York: Museum of Modern Art \& Florence: Centri Di, 1972.

10. Michael Sorkin, ed., Variations on a Theme Park: The New American City and the End of Public Space, New York: Hill and Wang, 1992

Introduction -21 
entertainment that originated as communal have been transferred to the private sphere by means of the television and computer. Today, one predominant concern seems to be determining the character of contemporary urban space: security. The open spaces of the city, streets and squares, along with communal spaces, have above all become spaces of fear, and thus, inevitably, spaces of control. Fear is a primary force driving the proliferation of socially homogeneous and controlled enclaves, gated communities, and theme parks. And it is fear that determines the definition of what is left of public space.

To keep fear - all the various forms of fear that have possessed us - at bay, we have resorted to remedies such as the illumination of public space, its enclosure and segregation, and video surveillance. According to Steven Flusty, certain characteristics are introduced into urban spaces in order to make them repellent to the public. Zygmunt Baumann points out that, on the contrary, urban space ought to be shaped by the concept of "mixophilia," to favour and encourage the possibility "of living peacefully and happily with difference, and taking advantage of the variety of stimuli." ${ }^{11}$ To achieve this end, it would be necessary to promote "the diffusion of public spaces that are open, inviting, and hospitable, spaces that citizens of all kinds of would be tempted to make frequent use of and to share intentionally and willingly." ${ }^{12}$ What qualities should these spaces have? Is it possible to transform the urban spaces described by Flusty into livable, appealing, and interesting environments? As early as the 1960s, in her critique of planning practices, Jane Jacobs suggested some possible qualities of the urban environment, stressing the importance of difference, of the human dimension, and insisting on the role of the street as public space. ${ }^{13}$ In his influential text of the 1980s, William H. Whyte also proposed the street and the square as public spaces par excellence, analyzing their modes of use and their various components, from water to wind, from trees to light, from shade to sun, arriving at the idea of a "sensorial street." $^{14}$

Nonetheless, city planning has long privileged qualities of urban space based exclusively on visual perception. Whether the aim was to define a regular space through control of alignments and heights or through definition of materials and colours, or to accentuate contrasts and differences in a picturesque vision of the urban environment, the eye has always been privileged. The same consideration has not been given to the ear and nose (nor the sense of touch). Above all, sounds and odours have been considered disturbing elements, and architecture and city planning have exclusively been concerned with marginalizing them, covering them up, or eliminating them altogether.

\section{From the hygienic city to smellscapes and soundscapes}

This process of sanitization of the urban environment, although it was prefigued at the dawn of the Italian Renaissance by "Leonardo Bruni in his "Panegyric to the City of Florence" (circa 1403-04), ${ }^{15}$ is only taken up in earnest at the level of the municipality in the mid-eighteenth

11. Zygmunt Bauman, Living with Foreigners, address to the conference Trust and Fear in the City, Unidea, Unicredit Foundation, Società Umanitaria, Milan, March 30, 2004, proceedings published as Fiducia e paura nella città, Milan: Bruno Mondadori, 2005, 33; translation from the Italian by the author 12. Baumann, Living with Foreigners, 35

13. Jane Jacobs, The Death and Life of Great American Cities, New York: Modern Library, 1962

14. William H. Whyte, City: Rediscovering the Center, New York: Doubleday, 1988

15. Florentine humanist Leonardo Bruni, chancellor of the republic from 1427, wrote his Laudatio florentinae urbis in conscious imitation of a $2^{\text {nd }}$ century $A D$ panegyric on Athens. The first Renaissance writer to utilize an ancient literary model for a contemporary text, Bruni nonetheless departs in crucial ways from the Greek model, describing the architecture and character of the city in wholly new terms; published in English trans. by Benjamin G. Kohl, in Hans Baron, From Petrarch to Leonardo Bruni: Studies in Humanistic and Political Literature, Chicago: Published by the Newberry Library for the University of Chicago Press, 1968, 232-263 
century. ${ }^{16}$ The transformation of the character and quality of public space starts with the first regulations concerning street cleaning and attempts to control the proliferation of dust and mud by paving streets with stone, and subsequently, asphalt. Even with respect to garbage collection and the elimination of dirt and odours, the visual aspect of the intervention, whether it was paving or plastering, assumed a predominant role, often in excess of what was actually required. ${ }^{17}$

This dual preoccupation with the visual and the "hygienic" has been a constant factor in the shaping of attitudes toward the modern city, and it persists today. Thus, the paving of roads and squares, street lighting, and regulations to prevent the spread of unpleasant odours and noises were just the first step in the ongoing process of embellishing public space. ${ }^{18}$ With the introduction and dissemination of new technologies (now on an increasingly global scale), and the consequent production of new and more or less undesirable effects of a sensory nature, solutions considered optimal at one moment come to be perceived as problematic, in and of themselves, at a later point. This is the case with asphalt, which is now blamed for the increase in automobile traffic, and also street lighting, which has resulted in excessive illumination of the city at night.

However, the continuous erosion of the perceptual sphere, by sanitization on the one hand and standardization on the other, has to contend with olfactory and aural distinctions, which however impalpable, have turned out to be highly resistant. The processes of globalization and the diffusion of now-common odours (that mixture of gasoline, detergents, plumbing, and junk food of which Ivan Illich speaks) ${ }^{19}$ notwithstanding, every city and every place still has its own smellscape: "There is a smell of London. There is a Russian smell.... There is a smell of Central Europe.... There are scents of the Mediterranean and the Orient.... There is the subtlety of the odours of India.... There are the odours of China... There is the smell of America," observes André Siegfried, one of the first writers to take an interest in the geography of colours, odours, and sounds. ${ }^{20}$ Likewise, the research of Murray Schafer and the laboratoire CRESSON has focused on the study of diversity in soundscapes of urban environments. ${ }^{21}$ Thus, alongside the traditional notion of a visual landscape, we have begun to recognize the identity of individual cities by their unique sounds and smells. One need only look at recent rise of recorded soundscapes as a form of "guide" to cities around the world,

16. For an analysis of the relationship between the city and the human body, see Richard Sennett, Flesh and Stone: The Body and the City in Western Civilization, New York: W. W. Norton, 1994

17. Rodolphe el-Khoury, Polish and Deodorize: Paving the City in Late-Eighteenth-Century France, in Assemblage, December 1996: 6-15

18. It is worth recalling the Futurists' appreciation for the new noises of the modern city. See Luigi Russolo, L'arte dei rumori: manifesto -futurista, Milan: Direzione del movimento futurista, March 11, 1913; Milan: Edizioni Futuriste di Poesia, 1916; published in English as The Art of Noises, transl. and introd. Barclay Brown, New York: Pendragon Press, 1986

19. Ivan Illich, $\mathrm{H}_{2} \mathrm{O}$ and the Waters of Forgetfulness, London: Marion Boyars, 1986, 49-50 20. André Siegfried, La Géographie des odeurs, lecture delivered in Paris in 1947, published in Géographie des odeurs, eds. Robert Dulau \& Jean-Robert Pitte, Paris \& Montréal: Éditions L'Harmattan, 1998, 19-23. For a history of the perception of smells, see Alain Corbin, Le miasme et la jonquille. L'odorat et I'imaginaire social, Paris: Aubier, 1982. For a general approach to the theme, see also his Histoire et anthropologie sensorielle, first published in Anthropologie et Sociétés 14/2 (1990), and later in Les Temps, le désir et l'horreur: Essais sur le dix-neuvième siècle, Paris: Flammarion, 2000, 228-241, and Time, Desire, and Horror: Towards a History of the Senses, trans. Jean Birrell, Cambridge, Mass.: Polity Press, 1995

21. A basic introduction to the work of R. Murray Schafer can be found in The Soundscape: Our Sonic Environment and the Tuning of the World, Rochester, Vermont: Destiny Books, 1977. Also of interest is the research into the sonic landscapes conducted by the Laboratoire CRESSON at the University of Grenoble. Among the publications coming out of this work is Jean-François Augoyard \& Henry Torgue, À l'écoute de l'environnement. Répertoire des effets sonores, Marseilles: Éditions Parenthèses, 1995 
or the insightful sound installations and "walks" of Canadian artist Janet Cardiff, to grasp the importance of this new alertness to sounds and noises in the urban environment.

\section{Architecture and sensorial experience}

It is not just the urban setting in which we live that changes with the passing of time, but our own perceptions, sensitivities, and ways of life as well, as our sensory thresholds and levels of tolerance or appreciation of odours, sounds, dirt, darkness, cold, or heat vary. However, this variation in perception and sensitivity, and thus judgment, does not depend solely on time, but also on location and culture. ${ }^{22}$ The abstract idea of a modern human being who prefers, for example, to live at an ambient temperature of $18^{\circ} \mathrm{C}$ has given way to a multitude of contemporary human beings who live in different places and cultures, with different levels of awareness and tolerance. ${ }^{23}$ In contrast to what Charles Moore suggested in the 1970 s, ${ }^{24}$ we do not "live" in a generic body, but in bodies that differ widely in their perceptual culture and capacities, and that are sometimes even modified by technological prostheses. As David Howes has observed in connection with Marshall McLuhan's research, "perception is not just a matter of biology, psychology, or personal history, but of cultural formation." ${ }^{25}$ In recent years, the human and social sciences, from anthropology to geography, have undergone a "sensorial revolution" in which the "senses" constitute not so much a new field of study as a fundamental shift in the mode and media we employ to observe and define our own fields of study.

Much of contemporary architecture shares this renewed interest in a sensorial experience extending beyond the purely visual realm. Architects including Gaetano Pesce, Jacques Herzog, Juhani Pallasmaa, Steven Holl, Kengo Kuma, and even Peter Eisenman have pointed out that too much importance is given to the visual aspect of architecture. "Yes, sound, material, not just vision. What I'm trying to do is to question the dominance of vision and this is a difficult thing because most people are judged by the visual image. There is too much visual noise in our environment for me" remarked Peter Eisenman in a recent interview. $^{26}$

In their description of the "conglomerate order," Alison and Peter Smithson hypothesized that a building can "harnesses all the senses: it can accept a certain roughness, it can operate at night; it can offer, especially, pleasures beyond the eyes: they are perhaps the pleasures of territory that the other animals feel so strongly." 27

Contemporary interiors - from hospitals to the communal spaces of shopping malls, theme parks, and places of entertainment and consumption - devote particular attention to diffe-

22. On the subject of sounds, it is very interesting to look at the data provided by $R$. Murray Schafer on noises perceived as annoying in different cities at the beginning of the 1970s, which is cited in The Soundscape, mentioned above, and also in this volume, 170-171.

23. Reyner Banham, The Architecture of the Well-tempered Environment, Chicago \& London: University of Chicago Press, 1969, 40

24. Kent C. Bloomer \& Charles Moore, Body, Memory, and Architecture, New Haven and London: Yale University Press, 1977

25 David Howes, Introduction, in Empire of the Senses: The Sensual Culture Reader, ed. David Howes, Oxford and New York: Berg, 2005, 3-4. This is an interesting foray into the sensual revolution that has taken place in the human and social sciences.

26. Peter Eisenman interviewed by Chiara Visentin in Genoa, 2004; now at www.floornature.com 27 Alison \& Peter Smithson, Italian Thoughts, privately published in Sweden, 1993, 62. See also Juhani Pallasmaa, The Eyes of the Skin: Architecture and the Senses, London: Academy Editions, 1995, and Steen Eiler Rasmussen, Experiencing Architecture, Cambridge, Mass.: The MIT Press, 1964. A new attempt to tackle the theme in comprehensive fashion can be found in Joy Monice Malnar \& Frank Vodvarka, Sensory Design, Minneapolis: University of Minnesota Press, 2004. Noteworthy is the fact that a Sensory Trust has been established. (www.sensorytrust.org.uk) 
rences in sensory perception, and many are conceived specifically as extensions of marketing strategies for consumer goods and experiences. A growing number of the objects that surround us are designed with a special emphasis on their sensual characteristics. In the field of communication of abstract information, for example, Saul Wurman's information design ${ }^{28}$ has been superseded by new research that focuses on multi-sensory design, introducing the aspects of sound and touch as well. ${ }^{29}$ This interest is currently even influencing the design of virtual environments.

At a moment when sensory marketing, purveyors of the experience economy, and the practice of multi-sensory design, not to mention the crucial investigations of contemporary artists, seem to be devoting so much attention to sensorial experience, it is paradoxical to find that the urban environment remains untouched by this sort of consideration.

\section{Character, atmosphere, and sensorial urbanism}

Critical thinking in this context is no longer driven by language, semiotics, text, and signs, but by a rediscovery of phenomenology, experience, the body, perceptions, and the senses. This "sensorial revolution" has been matched in architecture and urbanism by a rediscovery of the element of character. ${ }^{30}$ Associated with a particular place, the term character indicates its specificity; at the same time it does not refer to an exclusively visual condition, but embraces all the various sensory experiences that one can have in a place. As far back as the 1970s, Kevin Lynch ${ }^{31}$ and Christian Norberg-Schulz reintroduced this theme into their reflections on the urban environment. In particular, Norberg-Schulz described place as a "total" qualitative phenomenon, making use of expressions like "environmental character" and "atmosphere." ${ }^{32}$

It is precisely this last term which is increasingly being used to describe the environmental qualities of a place. ${ }^{33}$ Gernot Böhme has portrayed atmosphere as an almost objective condition. It implies the physical presence of the subject and the object; it focuses attention on place; and above all, it presupposes a sensory experience. Böhme has observed that "sensory perception as opposed to judgment is rehabilitated in aesthetics, and the term 'aesthetic' is restored to its original meaning, namely the theory of perception." ${ }^{34}$ Yet it is not just a question of developing a new sensitivity. As Reinhard Knodt has pointed out, specific expertise is also necessary, an expertise that is extended to the practical field through the work of artists, architects, city planners, or landscape designers. ${ }^{35}$ In establishing a "sensorial city planning" that is capable of defining the character and atmosphere of places, it is necessary to avoid a practice based, once again, on vision. The discipline of landscape design cannot

28. See Richard Saul Wurman, Information Architects, New York: Graphis Press, 1996

29. Keith V. Nesbitt, Modelling the Multi-Sensory Design Space, in Peter Eades \& Tim Pattison, eds., Australian Symposium on Information Visualization, Conferences in Research and Practice in Information Technology 9, Sidney: Australian Computer Society, 2001

30. See the entry for "carattere" in Luciano Semerani, ed., Dizionario critico illustrato delle voci più utili all'architetto moderno, Venice: Fondazione Angelo Masieri \& Faenza: Edizione CELI, 1993, and for "character" in Adrian Forty, A Vocabulary of Modern Architecture, London: Thames and Hudson, 2000 31. Kevin Lynch, The Image of the City, Cambridge, Mass.: MIT Press, 1960

32. Christian Norberg-Schulz, Genius Loci: Towards a Phenomenology of Architecture, New York: Rizzoli, 1984, first published in Italian, as Genius loci: Paesaggio, ambiente, architettura, trans. Anna Maria Norberg-Schulz, Milan: Electa, 1979

33. On the the use of the term atmosphere in architecture and city planning, see Konstruktion von Atmosphären, Daidalos 68, 1998

34. Gernot Böhme, Atmosphere as an Aesthetic Concept, Daidalos 68, 1998, 114. See also his Atmosphäre: Essays zur neuen Ästhetik, Frankfurt-am-Main: Suhrkamp, 1995, and Anmutungen, über das Atmosphärische, Ostfildern: Edition Tertium, 1998.

35. Reinhard Knodt, Atmosphären, in Ästhetische Korrespondenzen: Denken im technischen Raum, Stuttgart: Philipp Reclam, jun., 1994

Introduction -25 
help in this regard, for it, too, like architecture and city planning, is dominated by the eye. Unfortunately, as Iñaki Ábalos points out, "true picturesque invention - in which places have a voice and speak to us, telling us what they expect to become, what they need or do not need - has developed ... as pure appearances, as cosmetics." ${ }^{36}$

According to Kengo Kuma, there is another, non-visual practice to which we can turn for reference in this regard: "The practice of gardening provides us with many hints and gives us the courage. ${ }^{\prime 37}$ In fact, it is not just a matter of reducing our dependence on vision and introducing richer conditions of perception; there is also the need to "make manifest that totality called place." ${ }^{38}$ The gardener is always in the garden, he is practically its prisoner. There being no distance between him and the garden, he cannot manipulate it visually from the outside, as a landscape designer would do. "He is forever occupied with watering, ridding plants of bugs, weeding and replanting, and the garden would cease to exist if he stopped... There is no temporal point where a goal is reached and completion is achieved. There is no completion for a garden." ${ }^{39}$

We have to find a different way of talking about, describing, and planning our cities that suggest thinking of them as places for our bodies (and our souls) $;^{40}$ remember how mutable is our way of perceiving the urban environment; construct a history of the changes in the Western city from new points of view that have been hitherto neglected; in addition, we need to discover the possibilities provided by the urban environment in its various aspects those of sound, smell, touch, vision, and climate - and to look at them in new ways.

The physical urban environment, despite the impoverishment to which it is currently subject, is in fact a vital part of our human experience. As Joseph Rykwert points out, the seduction of place still exists, and the spread of cyberspace will not be able to substitute for "the functions of the tangible public realm." ${ }^{41}$ On the contrary, it is precisely the expansion of the virtual, globally connected world that renders specific places increasingly appealing and thus important. The fact that accessibility is no longer the discriminating factor makes the other qualities of a place fundamental to its ability to attract. ${ }^{42}$

Thus atmosphere, character, and sensorial qualities are becoming key factors in the definition of a place, even from an economic perspective. All the more reason for us to demand that this attention be turned to public places, and to urban spaces in general. Is it possible to combine the different approaches to contemporary urbanism with a "sensorial urbanism," capable of offering a broader understanding of urban settings, interested in describing the character and atmosphere of places, and aiming to contribute to a new definition of public space?

36. Iñaki Ábalos, Metamorfosi pittoresca, in Metamorph, Focus, catalogue of the $9^{\text {th }}$ International Exhibition of Architecture, Venice: Venice Biennale, 2004, 147. English edition, Picturesque Metamorphosis, in Metamorph, Focus, Vectors, Trajectories, eds. Kurt W. Forster \& N. Baltzer, Venice: Marsilio, 2004 37. Kengo Kuma, Gardening vs. Architecture, in Lotus International 97, June 1998, 46-49

38. Kuma, Gardening vs. Architecture, 49

39. Kuma, Gardening vs. Architecture, 49

40. It is worthwhile to reread some of James Hillman's writings on the city. See in particular City and Soul, Dallas: Center for Civic Leadership, University of Dallas, 1978.

41. Joseph Rykwert, The Seduction of Place: The History and Future of the City, $2^{\text {nd }}$ ed., New York: Vintage Books, 2002, 159

42. William J. Mitchell, The Revenge of Place, in Kester Rattenbury, ed., This is Not Architecture: Media Constructions, London \& New York: Routledge, 2002, 45-53. In this connection, see also François Ascher, Métapolis ou l'avenir des villes, Paris: Éditions Odile Jacob, 1995, 263. 